\title{
BICENTENÁRIO DO POETA FRIEDRICH VON SCHILLER
}

Reinaldo Bossmann

Freude, schöner Götterfunken,

Tochter aus Elysium,

Wir betreten feuertrunken, Himmlische, dein Heiligtum.

Deine Zauber binden wieder, Was die Mode streng geteilt, Alle Menschen werden Brüder, Wo dein sanfter Flügel weilt.

Seid umschlungen, Millionen!

Diesen Kuss der ganzen Welt!

Brüder - überm Sternenzelt

Muss ein lieber Vater wohnen.

Alegria, centelha dos deuses,

Bela filha do Eliseu,

Embriagados de ardor

Entramos no Santuário teu!

Tua magia liga, novamente,

O que o gládio separou,

E por onde estendeste a aza meiga,

A humanidade toda se irmanou.

(Tradução livre de Amelia de Rezende Martins).

São os versos iníciais de "An die Freude" - "Ode ao fúbilo" de Schiller que Beethoven usou no côro final de sua IXa. Sinfonia. Como foi, que o poeta se expressou! Belas e majestosas palavras empregou para êste nobre pensamento! Uma linguagem patética, mas exata e clássica da mais profunda fonte de toda existência artística, do esfôrço e da experiência de uma arte verdadeira. 
No mais profundo ser de Schiller destaca-se sempre o puro $e$ inocente infante, enobrecente simplicidade, ao lado de uma santa seriedade, ligado a um potente raciocínio. Esses traços especiais fazem sempre a sua grandeza específica e incomparável, à qual o velho sábio de Weimar, Goethe, em suas palestras, não cansava de louvar. Disse o autor de "Fausto": "Schiller mochte sich stellen, wie er wollte, er konnte gar nichts machen, was nicht immer bei weitem grösser herauskam, als das Beste der Neueren; ja wenn Schiller sich die Nägel beschnitt, war er grösser als diese Herren." - "Schiller, em tôdas as suas atitudes, nada podia fazer, sem que aquilo que fizesse, fôsse mais magnífico do que o melhor dos renovadores". Numa outra passagem Coethe observou: "Schiller war ein grosser, wunderlicher Mensch." - "Schiller era um grande e singular homem." Um grande e singular homem, isto é a melhor apreciação para com o seu amigo tão prematuramente falecido. A existência de Schiller, embora continuamente ameaçada de cedo desaparecimento, era, no mais alto grau, religiosa. Em nenhuma fase de sua doença, essa religiosidade deslizou para o caótico. A grandiosidade, o emocionante de sua crença paradoxa é a tentativa de purificar e idealizar o mundo.

Quais são os valores eternos no testamento dêsse grande $e$ singular homem e poeta? A dialética entre um nobre ego e o mundo. Sua saudade à amizade e seu impulso criador, isolando e recaindo sôbre si mesmo, sua fé nos homens e sua melancolia hipocôndrica, que muitas vêzes o atacou, em conseqüencia de experiências prematuras oriundas de doenças e do frágil estado do próprio ser. Partindo dêstes fatos, devemos compreender os temas e os sentimentos do poeta. Êstes são os polos de sua liberdade e do seu mundo exterior, do seu ideal e vida, do sentimento da união da alma com o corpo, nas alegrias e nos sofrimentos dêste, da coragem e libertação, do firme propósito de sobrepujar as condições adversas do seu físico.

O elevado pensamento do poeta, seu ímpeto ao grandioso, sua simpatia para com o extraordinário aparecem cedo, e sempre ficam e pertencem à sua natureza aristocrática.

Assim, Schiller é uma individualidade poderosa. Mas, a in- 
dividualidade não se torna um tema, nem a própria, nem em geral. Suas obras não são confissões pessoais, suas amizades não são românticas. Seu querer artístico é unido a seus esforços políticos, morais e teológicos, alvejando sempre o total, o objetivo e os valores da humanidade.

Suas narrações e suas obras históricas são unilaterais $\mathrm{em}$ suas criações. $\mathrm{Na}$ avaliação de suas obras não se deve ser inflexível para apurar a diferença entre a imaginação e fatos documentados. Através dos pontos de vista da ciência moderna, suas exposições históricas não podem ser medidas. Elas são sempre transformaçōes livres, vistas pelo prisma de um poeta. Suas narrações, também aquelas que não estão baseadas em documentos, querem e devem ser sempre verdadeiras, são sempre pragmáticas e objetivas, ilustrando fatos contemporâneos e sêres humanos típicos.

O homem Schiller não era na vida prática o estranho idealista, como muitas vêzes é apresentado. Isto é uma pura lenda. Schiller era antes de tudo diplomático, calculando e trabalhando com o objetivo de utilizar-se de homens e situações. Seu encontro decisivo com Goethe, que resultou em amizade recíproca, depois de muitos anos de um esquivo consciente de contactos, não foi obra do acaso, mas sàbiamente arranjado pelo próprio Schiller.

Era Württemberg a paisagem cultural da qual o seu espírito crescente se nutria. Apesar da miséria, quão rica em tradições espirituais regionais era a Alemanha daqueles tempos! $\mathrm{E}$ quão pobre se tornou pela fôrça do nacionalismo! Quão marcantes eram em Württemberg o pietismo e o racionalismo suábico, fundidos com a existência do Ducado. Aqui, pensamentos críticos eram dirigidos ao Estado, não só ao religioso, mas, também ao político, isto é, especulações políticas e teológicas formavam um fim comum, a saber: ser sério, piedoso e revolucionário. Aqui, no berço em Württemberg o pietismo e o racionalismo suábico, fundidos damentos do conceito do poeta sôbre História e Liberdade, mesmo que êle, depois, o modificasse pela filosofia de Kant, por seus estudos históricos e pela lei própria de gênio criador.

Devido a uma tradição regional rica, Schiller, o cosmopolita, 
sempre permaneceu filho de sua terra natal, um suábio.

Dona Isabel:

"Oh! Filhos meus! Hostil e falso é o mundo,

$E$ mal intencionado! Ama sòmente

Cada qual a si próprio. Incertos, frouxos

E variáveis são os laços todos

Que da fortuna alígera são filhos.

O que o capricho atou, solta o capricho:

Leal só a natureza: Ela, sòmente,

Firme repousa em âncoras eternas,

Enquanto sôbre as ondas procelosas

Da vida, tudo o mais flutua instável.

- Amigo a inclinação, sócio e proveito

Nos granjeia. Feliz, porém, daquele

Que um irmão deve ao berço! Não tho pode

Outorgar a fortuna - tem congênito

$O$ amigo leal que duplicado contra um mundo

De engano e guerras cheio se abalança"...

Schiller, de "A Noiva de Messina", tradução por Antônio Gonçalves Dias.

"Pelas ruas da cidade

Acompanhada de dor

Vai de rôjo a infelicidade

Com olhar prescrutador.

Dos homens na casa espia.

Hoje bate ela

Nesta porta, - e além -

Amanhã naquela

Sem se doer, sem perdoar alguém!

Aborrecida,

Não tem tardar,

Vem cedo ou tarde

Ao limiar

Onde esteja quem quer que tenha vida"!

Vozes de um dos coros, de "A noiva de Messina", tradução por Antônio Gonçalves Dias. 
O paz benévola,

Concôrdia amável!

Nesta cidade

Sorri sempre amorável!

Um só dia não brilhe

Em que a raivar da guerra

Turve êsse val tranqüilo,

Em que o céu

Tão belo do crepúsculo

No purpurino véu,

llumine-se aos hórridos clarões

Do incêndio a lavrar nas povoações!

Trecho de "O Canto do Sino" de

Schiller, tradução por Bernardo

Taveira J. 